\title{
Unilateral Complete Ureteral Duplication with Impacted Stone at Ectopic Opening of Upper Moiety Ureter in Posterior Urethra and Simultaneous Bladder Stone: A Rare Entity
}

\author{
R S Sisodiya*, Parveen Kumar and S K Sinha \\ Department of peadiatric surgery, Maulana Azad medical college and Lok Nayak Hospital, India
}

Submission: November 14, 2016; Published: February 08, 2017

*Corresponding author: R S Sisodiya, Department of peadiatric surgery, Maulana Azad medical college and Lok Nayak Hospital, New Delhi, India, 110002, Email: sisodiyarajpalsingh@yahoo.in

\begin{abstract}
Complete ureteral duplication with ectopic upper moiety opening into posterior urethra is rare anomalies. This is due to development of two ureteric bud from mesonephric duct. Development of stone in this moiety is rare event. Here we are describing a 12 year old child who presented with left lumbar mass and dysuria. He had left complete duplex ureter with impacted stone at ectopic opening of upper moiety ureter in posterior urethra, simultaneous bladder stone and hydronephrotic non-functioning upper renal moiety. Combined (cystourethroscopy and open surgical) approach was used for management of this case.

Keywords: Ectopic ureter; Duplex renal moiety; Stone in duplex kidney
\end{abstract}

\section{Introduction}

Duplex system can be describes as two pelvicaleceal system with either single lower ureter or double ureter draining into bladder or outside the bladder (ectopic) [1,2]. Duplex system with double ureter and ectopic opening of upper pole ureter into proximal urethra (ectopic) is rare anomalies compare to bifid ureter [1]. Stone formation in duplex system is potential complication [1,3-5]. Combined approach should be used to deal such situation in resource poor setting.

\section{Case Report}

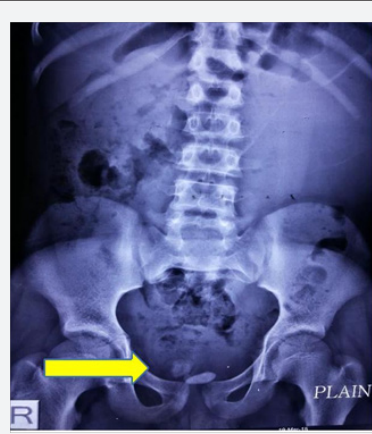

Figure 1: Showing two radiopaque shadow in pelvis (yellow arrow).

Twelve year old male child presented with complain of colicky pain with mass in left lumbar region and dysuria since
5 month. No history of fever, hematuria or trauma to abdomen. Examination revealed single $10 \mathrm{~cm} \times 8 \mathrm{~cm}$ nontender cystic ballotable mass in left lumbar region. Complete blood count was normal, urea $32 \mathrm{mg} \%$, creatinine $0.6 \mathrm{mg} \%$ Ca $9 \mathrm{mg} \%$ uric acid $5.6 \mathrm{mg} \%$ PO4 5.3mg\%, urine microscopy 25 pus cells/HPF, urine culture no growth, Plain X-ray shows two radiopaque shadow in pelvis (Figure 1), USG shows Right kidney Normal, Left upper moiety gross hydronephrotic, left ureter dilated till lower end, lower moiety normal, Stone in urinary bladder $(1.5 \mathrm{~cm})$ and Left VUJ $(1.6 \mathrm{~cm})$. Intravenous urogram (IVU) and nuclear imaging suggestive of left upper moiety nonfunctioning (Figure $2 \& 3$ ), left lower moiety normal. Right kidney normal.

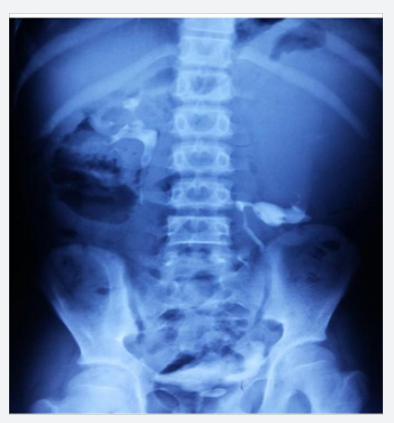

Figure 2: IVU showing left upper non- functioning moiety. 


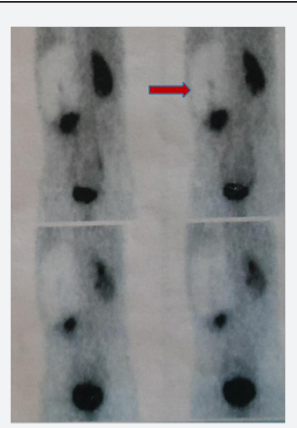

Figure 3: DTPA Scan showing left non- functioning upper moiety (red arrow) and normal function of lower moiety.

During cystourethroscopy one stone was impacted at ectopic opening of ureter and projecting into posterior urethra in curvilinear fashion and another stone in urinary bladder, stone at ectopic opening was disimpacted and pushed backed into ureter and child was catheterized. Open left upper pole nephrouretectomy with removal of ureteral stone and cystolithotomy was performed.

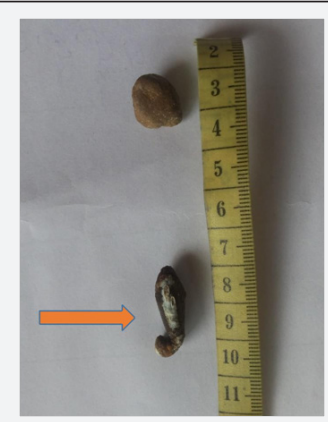

Figure 4: Showing post -operative specimen upper stone was from urinary bladder and lower stone from lower end of left upper moiety ureter (orange arrow).

Figure 4 (specimen) showing stone of urinary bladder (upper) and impacted stone of ectopic ureter (red arrow). Post operatively child recovers well and on 6 month follow up child was well.

\section{Discussion}

Duplex system with double ureter with ectopic opening of upper moiety ureter into posterior urethra in male child is rare anomalies $[1,6]$. In duplex system lower moiety is usually good functioning and upper moiety having ectopic opening of ureter is hydronephrotic and poor or nonfunctioning [7,8], as in our case. Ureteral duplication with ectopic upper moiety ureter in male child is usually asymptomatic. These duplex systems are vulnerable for urinary tract infections and urolithiasis. Urinary calculi are often due to relative stasis of urine but may occur due to factors unrelated to the duplication. Development of stone in upper moiety ureter may be due to either obstruction, recurrent infection or other factor. Treatment of nonfunctioning upper moiety is surgical removal [7].

Retrieval of large stone per urethrally is difficult task in setting where lithotripter is not available. In this case we had to disimpact and push backed the stone into the ureter so that we could be able to remove stone by open surgery.

Duplex moiety with impacted stone in lower end of upper moiety ureter can be dealed with combined approach (cystoscopy and open) in resource poor setting.

\section{References}

1. Karakose A, Aydogdu 0, Atesci YZ (2013) Unilateral complete ureteral duplication with distal ureteral stone: A rare entity. Can Urol Assoc J 7(7-8): E511-E512.

2. Prakash, Rajini T, Venkatiah J, Bhardwaj AK, Singh DK, et al. (2011) Double ureter and duplex system: a cadaver and radiological study. Urol J 8(2): 145-148.

3. Chahed J, Jouini R, Krichene I, Maazoun K, Brahim MB, et al. (2011) Urinary lithiasis and urinary tract malformations in children: a retrospective study of 34 cases. Afr J Paediatr Surg 8(2): 168-171.

4. Alsayyad AJ (2016) Bilateral complete duplication of the ureters, with calculi simultaneously obstructing the four ureters. Urol Ann 8(2): 226-228.

5. Aiken WD, Johnson PB, Mayhew RG (2015) Bilateral complete ureteral duplication with calculi obstructing both limbs of left double ureter. Int J Surg Case Rep 6C: 23-25.

6. Handler TF, Shapiro E (2002) Incontinence in a child with a duplex kidney: case report. Rev Urol 4(1): 44-48.

7. Roy Choudhury S, Chadha R, Bagga D, Puri A, Debnath PR (2008) Spectrum of ectopic ureters in children. Pediatr Surg Int 24(7): 819823.

8. Senel U, Tanriverdi HI, Ozmen Z, Sozubir S (2015) Ectopic Ureter Accompanied by Duplicated Ureter: Three Cases. J Clin Diagn Res 9(9): PD10- PD12.
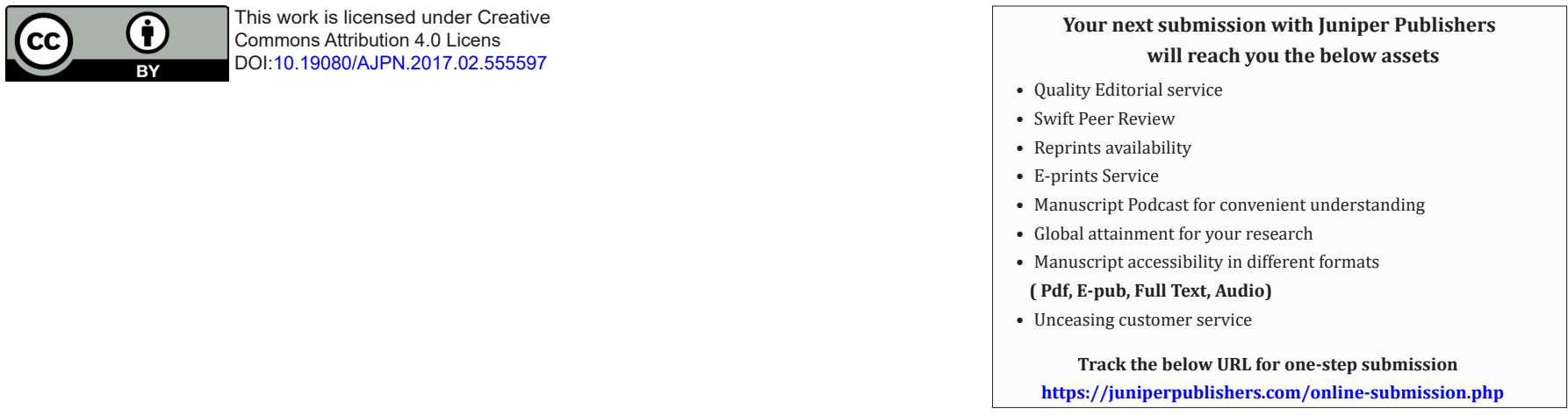